\title{
COVID-19 : EDUKASI DAN DESAIN INFOGRAFIS PENGGUNAAN MASKER UNTUK LINDUNGI KAMU DAN AKU
}

\author{
Meiskha Bahar ${ }^{1}$, Hany Yusmaini ${ }^{1)}$, Erna Harfiani1) \\ ${ }^{1)}$ Fakultas Kedokteran, UPN Veteran Jakarta, Jakarta, Indonesia \\ Corresponding author: Meiksha Bahar \\ Email: meiskha27@gmail.com
}

Diterima 25 November 2021, Direvisi 30 November 2021, Disetujui 30 November 2021

\begin{abstract}
ABSTRAK
Covid-19 merupakan masalah kesehatan global, belum ada obat yang terbukti efektif mengobati penyakit ini. Penularan Covid-19 terutama terjadi antar manusia, semakin dekat dan semakin lama interaksi maka semakin besar pula resiko penularan yang akan terjadi. Meningkatnya angka kejadian Covid-19 pertengahan tahun ini juga disebabkan oleh varian delta yang tingkat penularannya sangat tingggi dibandingkan dengan varian lainnya. Pemerintah Pusat melalui Kementerian Kesehatan Republik Indonesia pun telah mengeluarkan Surat Edaran Menteri Kesehatan Repubik Indonesia tentang Protokol Pencegahan Penularan virus Covid-19, yang salah satu caranya dengan menggunakan masker bagi masyarakat jika ingin keluar rumah. Hasil studi Centers for Disease Control and Prevention (CDC) menunjukan bahwa menggunakan Dua Lapis Masker efektif menyaring virus Covid-19 sampai dengan $90 \%$. Metode pelaksanaan kegiatan ini adalah melalui pemberian edukasi cara menggunakan masker (double masker) serta pelatihan cara membuat desain infografis mengenai Covid-19 dan penggunaan masker. Kegiatan dilakukan secara daring melalui zoom meeting pada 55 siswa SMA Negeri 1 Tambun Selatan Bekasi. Siswa diberikan pre dan post test pada saat pelaksanaan pelatihan untuk menunjukkan adanya peningkatan pengetahuan setelah pemberian pelatihan. Selain itu juga diadakan perlombaan pembuatan desain infografis yang diikuti oleh beberapa peserta. Dari kegiatan ini diharapkan peserta dapat membantu menyebarkan informasi kepada masyarakat mengenai pentingnya penggunaan masker (double masker) untuk mencegah penularan Covid-19
\end{abstract}

Kata kunci: covid-19; infografis; masker.

\begin{abstract}
Covid-19 is a global health problem, no drug has been proven effective in treating this disease. Covid19 transmission mainly occurs between humans, the closer and longer the interaction, the greater the risk of transmission that will occur. The increase in the incidence of Covid-19 in the middle of this year is also caused by delta variants whose transmission rate is very high compared to other variants. The Central Government through the Ministry of Health of the Republic of Indonesia has also issued a Circular Letter of the Minister of Health of The Republic of Indonesia on the Protocol to Prevent Transmission of the Covid-19 virus, which is one way to use masks for the community if they want to leave the house. The results of a Study by the Centers for Disease Control and Prevention (CDC) showed that using two layers of masks effectively filtered the Covid-19 virus up to $90 \%$. The method of implementing this activity is through the provision of education on how to use a mask (double mask) and training on how to create infographic designs about Covid-19 and the use of masks. The activity was conducted online through a zoom meeting on 55 students of State High School 1 Tambun Selatan Bekasi. Students are given pre and post-tests at the time of training to show an increase in knowledge after the training. In addition, there was also an infographic design competition that was attended by several participants. From this activity, it is hoped that participants can help spread information to the public about the importance of using masks (double masks) to prevent the transmission of Covid-19.
\end{abstract}

Keywords: covid-19; infographic; mask.

\section{PENDAHULUAN}

Coronavirus (CoV) merupakan bagian dari keluarga virus yang menyebabkan penyakit mulai dari flu hingga penyakit yang lebih berat seperti Middle East Respiratory Syndrome (MERS-CoV) dan Severe Acute Respiratory
Syndrome (SARS-CoV).(Novel Coronavirus, n.d.) Penyakit yang disebabkan virus corona, atau dikenal dengan COVID-19, adalah jenis baru yang ditemukan pada tahun 2019 dan belum pernah diidentifikasi menyerang manusia sebelumnya []. (Sari et al., 2020) 
Wilayah di Indonesia yang mengalami transmisi lokal adalah DKI Jakarta, Banten, Jawa Barat, Jawa Tengah, Jawa Timur, Bali (Kota Denpasar, Kabupaten Badung, Kabupaten Jembrana dan Kabupaten Buleleng), Kalimantan Selatan, Kalimantan Barat, Kalimantan Timur, Sulawesi Selatan, Sulawesi Tenggara dan Sumatera Selatan. Terjadinya transmisi lokal mengindikasikan bahwa telah terjadi penyebaran virus ditengah masyarakat lokal, tanpa harus bepergian ke luar wilayah atau bertemu dengan orang asing diluar wilayahnya (Utami \& Giri, 2020)

Kabupaten Bekasi merupakan salah satu wilayah yang beberapa kecamatannya memiliki angka Orang Dalam Pemantauan (ODP), Pasien Dalam Pengawasan (PDP) dan Orang Tanpa Gejala (OTG) yang cukup banyak sehingga perlu terus dilakukan sosialisasi tindakan pencegahan. Update tanggal 27 Juni 2020 tercatat 118 OTG masih dalam pemantauan, 72 PDP masih dalam pengawasan dan 61 ODP masih dalam pemantauan. Total terkonfirmasi positif sebanyak 246 orang, 20 orang diantaranya meninggal dunia.Beberapa upaya pemerintah dalam pemutusan rantai penyebaran covid 19 diantara ialah himbauan untuk perilaku hidup bersih dan sehat (PHBS), isolasi mandiri, social distancing, dan himbauan wajib menggunakan masker terutama saat keluar rumah untuk beraktivitas. (Armiani et al., 2020).

Manfaat utama memakai masker adalah termasuk membatasi penyebaran virus dari seseorang yang tahu atau tidak tahu jika mereka memiliki infeksi kepada orang lain. Masker diperlukan untuk semua orang agar tidak saling menularkan virus (Sii et al., 2020). Hasil penelitian yang dilakukan oleh Komisi Tetap Penyakit Menular dan Ancaman Abad 21 di Amerika Serikat mengatakan bahwa COVID19 bisa menular melalui percakapan dan penapasan normal dengan orang yang terpapar. Berdasarkan penelitian, Kemenkes (2020:2) memaparkan bahwa penyakit ini dapat menyebar melalui tetesan kecil (droplet) dari hidung atau mulut pada saat batuk atau bersin. Droplet tersebut kemudian jatuh pada benda disekitarnya. Kemudian jika ada orang lain menyentuh benda yang sudah terkontaminasi dengan droplet tersebut dan orang itu menyentuh mata, hidung atau mulut (segitiga wajah) maka orang itu dapat terinfeksi Covid-19. Masker diperlukan untuk semua orang agar tidak saling menularkan virus (Sii et al., 2020).

Peran media sosial yang begitu cepat menyampaikan broadcast ternyata cukup berhasil membuat masyarakat menjadi gampang percaya dengan berita-berita yang disebarkan oleh pihak atau sumber yang tidak jelas. Informasi yang simpang siur membuat masyarakat terbagi menjadi beberapa kelompok; kelompok masyarakat yang percaya dengan berita bohong (hoax) yang disebarkan oleh sosial media, kelompok masyarakat yang tidak gampang percaya dengan berita yang disebarkan lewat pesan berantai dan kelompok yang tidak peduli dengan kondisi saat ini.

Masyarakat perlu diberikan informasi yang benar, menarik dan informatif agar dapat bersama-sama menjaga lingkungan sekitar dan mencegah penularan Covid-19. Generasi muda, termasuk siswa sekolah SMAN 1 Tambun Kabupaten Bekasi yang saat ini aktif dalam media sosial tentunya dapat berkontribusi untuk membantu pencegahan penyakit dengan cara membuat infografis yang benar, menarik dan informatif tentang Covid-19 dan pencegahannya. Oleh karena itu kegiatan pengabdian masyarakat ini dilaksanakan di lingkungan sekolah, yaitu SMAN 1 Kabupaten Bekasi dengan tujuan agar siswa dapat menyampaikan informasi tentang manfaat penggunaan masker (double masker) untuk mencegah penyebaran virus Corona melalui pesan infografis.

\section{METODE} yaitu :

Kegiatan ini dibagi dalam tiga tahap,

a. Persiapan : Diawali dengan koordinasi dengan pihak sekolah tentang gambaran pelaksanaan, tujuan dan manfaat kegiatan serta metode yang akan digunakan pada pelaksanaan kegiatan pengabdian.

b. Pelaksanaan : Kegiatan pengabdian dilakukan secara daring melalui link zoom.link dibagikan melalui grup WhatsApp yang sudah dibuat sebelum kegiatan dilaksanakan dengan tujuan untuk menjadi wadah komunikasi dan berbagi info terkait pelaksanaan pengabdian. kegiatan pengabdian diawali dengan pre test dan diakhiri dengan post test untuk mengetahui sejauh mana pengaruh pemberian edukasi terhadap peserta. Pemberian edukasi oleh anggota pengabdi yang memiliki kepakaran dalam bidangnya masing-masing dan selanjutnya diberi pelatihan infografis oleh narasumber dengan latar Pendidikan desain grafis yang bertujuan agar siswa nantinya dapat menyebarkan informasi ini melalui hasil desain lewat media social.

c. Monitoring dan evaluasi : Setelah kegiatan pengabdian dilaksanakan, tim pengabdi mengadakan perlombaan pembuatan desain infografis yang berkaitan dengan tema dan nantinya akan dipilih pemenang dan mendapatkan hadiah. Hasil desain tiap peserta diwajibkan untuk ditampilkan pada laman media social mereka dan menyematkan tim pengabdi 
untuk selanjutnya dinilai. Penilaian berdasarkan konteks dan tampilan infografis.

\section{HASIL DAN PEMBAHASAN}

Hasil yang sudah dicapai dalam kegiatan pengabdian kepada Masyarakat ini adalah : Kegiatan ini diawali dengan persiapan peserta sebelum mengikuti penyuluhan (dengan pengerjaan kuesioner (pretest) lalu pembukaan dan ceramah penyuluhan oleh tim pengabdi dan Narasumber. Setelah ceramah, dilakukan tanya jawab dan pengumuman mengenai perlombaan pembuatan desain infografis tentang Covid-19 dan penggunaan Masker. Sebelum selesai peserta kembali mengisi lembar kuesioner (post test). Seluruh kegiatan dilakukan secara online melalui Zoom meeting.
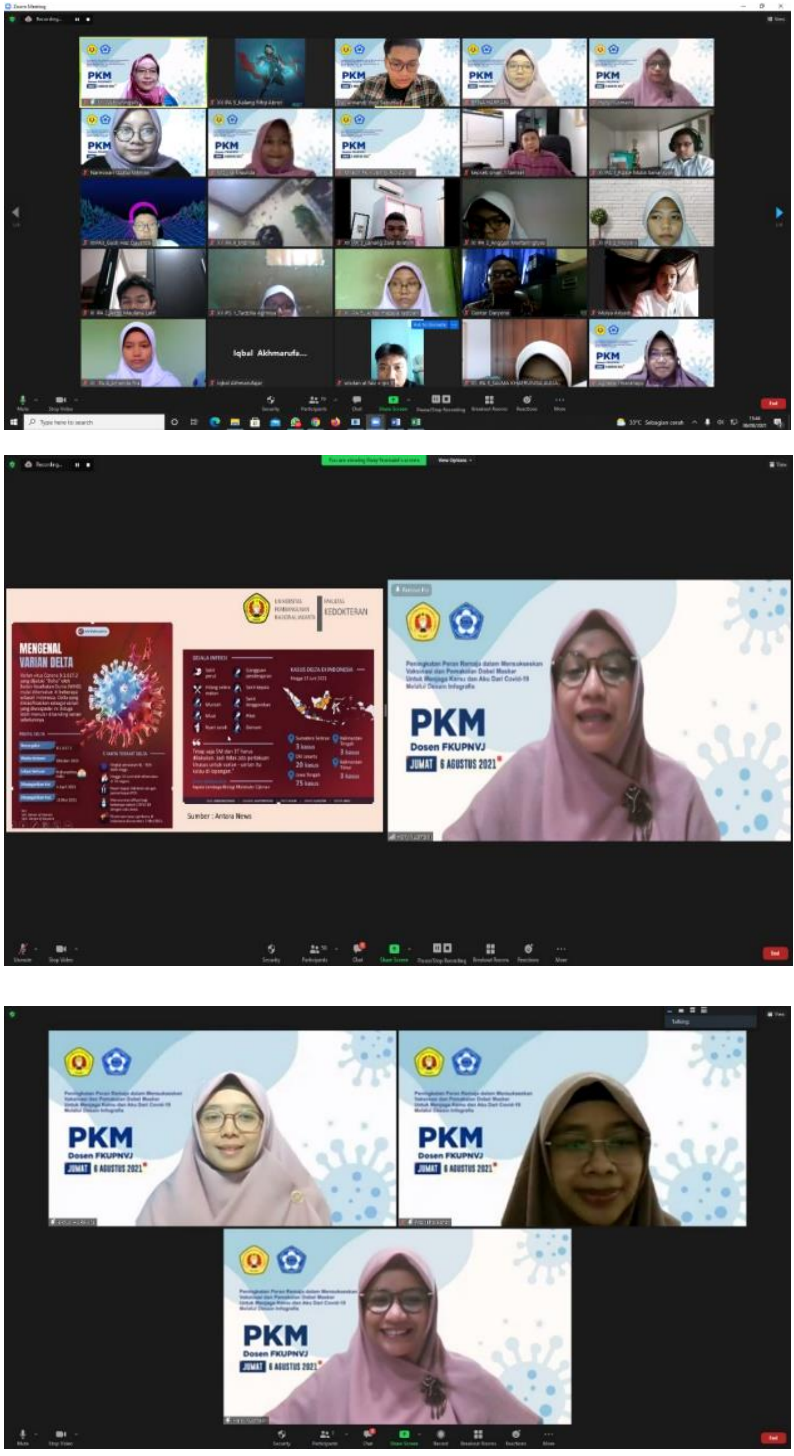

Gambar 1. Dokumentasi kegiatan penyuluhan secara daring (zoom meeting)

Hasil kuesioner menunjukkan bahwa terdapat peningkatan pengetahuan setelah peserta mendapatkan edukasi, hal ini terlihat dari hasil pre dan post test yang menunjukkan hasil yang signifikan dalam peningkatan pengetahuan.

Setelah kegiatan penyuluhan dilaksanakan, diadakan perlombaan membuat desain infografis bagi peserta yang kemudian dibagikan pada laman sosial media masingmasing peserta. Peserta harus membuat desain infografis tentang manfaat penggunaan double masker sebagai upaya untuk mencegah penyebaran Covid-19. Ada beberapa desain yang masuk dalam kriteria dan menunjukkan hasil karya yang cukup menarik dan informatif.

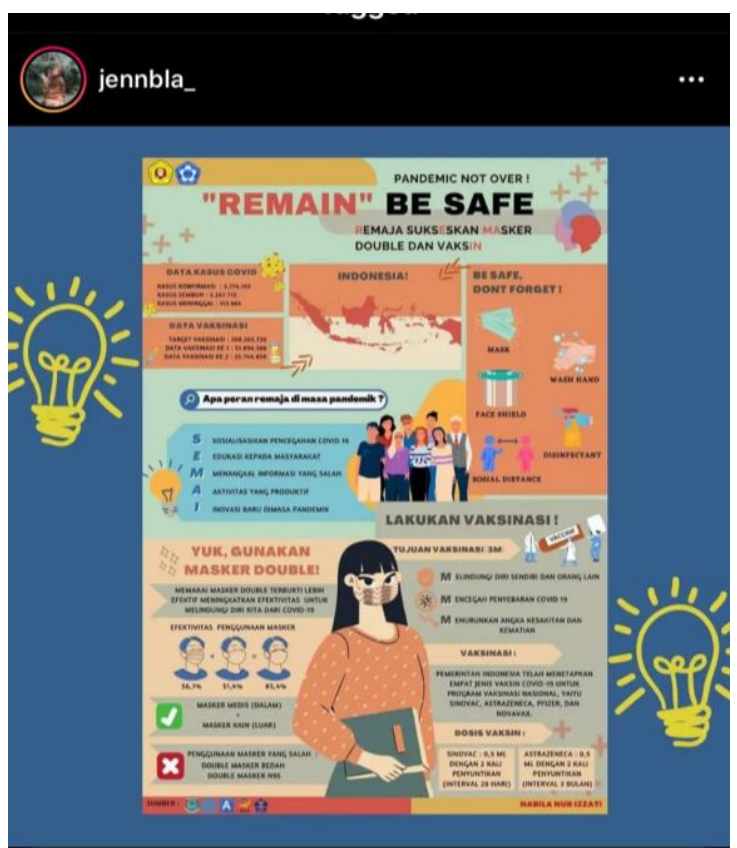

Gambar 2. Salah satu hasil desain infografis oleh peserta

Dari hasil kiriman peserta lomba, dapat dikatakan 100\% Sudah memenuhi kriteria karena isinya mengandung informasi tentang pentingnya penggunaan masker (double masker) didukung dengan data-data ilmiah dari sumber yang terpercaya dan ditampilkan dalam desain yang cukup menarik. Diharapkan informasi ini dapat tersampaikan dengan baik kepada masyarakat.

\section{SIMPULAN DAN SARAN}

Kegiatan pengabdian ini berjalan dengan baik dan lancar melalui media zoom meeting, pihak mitra dan peserta sangat senang dan merasakan manfaat dari edukasi tentang masker pelatihan pembuatan infografis yang telah diberikan. Lomba desain grafis juga menunjukkan hasil yang cukup baik. Semoga kegiatan ini dapat memberi manfaat bagi peserta dalam menyampaikan pentingnya 
penggunaan masker bagi masyarakat lewat desain grafis (infografis).

\section{UCAPAN TERIMA KASIH}

Pengabdi mengucapkan terima kasih kepada Kepala Sekolah SMAN 1 Kabupaten Bekasi yang telah memberikan ijin untuk pelaksanaan kegiatan pengabdian dan semua siswa yang sudah ikut menjadi peserta dalam kegiatan pengabdian. Dan juga kepada UPN Veteran Jakarta yang telah memberikan kesempatan dan biaya dalam pelaksanaan pengabdian ini

\section{DAFTAR RUJUKAN}

Armiani, S., Fajri, S., Sukri, A., \& Pidiawati, B. (2020). Pelatihan Pembuatan Masker Sebagai Upaya Antisipasi Penyebaran Covid-19 di Desa Anyar Kabupaten Lombok Utara. Jurnal Pengabdian UNDIKMA: Jurnal Hasil Pengabdian \& Pemberdayaan Kepada Masyarakat, 1(1), 22-27.

Novel Coronavirus. (n.d.). Retrieved November 2, 2021, from https://www.who.int/indonesia/news/novel -coronavirus

Sari, D. P., Sholihah, N., \& Atiqoh. (2020). HUBUNGAN ANTARA PENGETAHUAN MASYARAKAT DENGAN KEPATUHAN PENGGUNAAN MASKER SEBAGAI UPAYA PENCEGAHAN PENYAKIT COVID-19 DI NGRONGGAH. Infokes, 10(1), 52-55.

Sii, P., Iku, F. P., Warung, Y., Danu, A., \& Nesi, A. (2020). WUJUD KEPEDULIAN MELAWAN COVID-19 MELALUI KEGIATAN PEMBAGIAN 5.000 MASKER DAN HAND SANITIZER KEPADA MASYARAKAT DI PASAR PUNI RUTENG - MANGGARAI. Randang Tana: Jurnal Pengabdian Masyarakat, 3(2), 9399.

Utami, N. W., \& Giri, K. risna. (2020). GERAKAN 1000 MASKER MELAWAN CORONA: PEMBAGIAN DI KECAMATAN DENPASAR UTARA. JURNAL LENTERA WIDYA, Vol. 1 No. 